\title{
DAMPAK SINETRON INDONESIA TERHADAP PERILAKU MASYARAKAT
} (ANALISIS KASUS: SINETRON ANAK LANGIT DI SCTV)

\author{
Azwar ${ }^{(1)}$, Hreeloita Dharma Shanti ${ }^{(2)}$, Kintan Arumdhani ${ }^{(3)}$ \\ Program Studi Ilmu Komunikasi, FISIP Universitas Nasional “Veteran” Jakarta \\ Jalan RS Fatmawati, Pangkalan Jati, Cilandak, Cinere, Pangkalan Jati, Cinere, Kota Jakarta \\ Selatan, Jawa Barat 16514 \\ Email: (I) azwarstmalaka@upnvj.ac.id, (2) hreeloitads@yahoo.co.id, (3) kintandhani@gmail.com
}

\begin{abstract}
Abstrak
Penelitian ini bertujuan untuk mengungkapkan bagaimana perilaku masyarakat setelah menonton sinetron Anak Langit dan apa faktor yang menyebabkan perilaku masyarakat menjadi berubah setelah menonton sinetron Anak Langit tersebut. Selain itu penelitian ini juga akan melihat bagaimana pelanggaran yang terjadi dalam sinetron Anak Langit berdasarkan peraturan/regulasi penyiaran di Indonesia. Penelitian ini akan mengupas persoalan yang ada menggunakan Teori Kultivasi dimana teori ini berasumsi bahwa terpaan televisi berdampak terhadap masyarakatnya. Teori ini berlandaskan pada pemikiran Gerbner yang menyampaikan bahwa terpaan media yang terus menerus akan memberikan gambaran dan pengaruh pada persepsi pemirsanya. Artinya, selama pemirsa melakukan kontak dengan televisi mereka akan belajar tentang dunia, mengubah persepsi mereka akan dunia, belajar bersikap dan nilai-nilai orang. Penelitian ini menggunakan metode kualitatif, dimana peneliti melakukan studi pustaka, observasi dan wawancara untuk mendekati dan menggali persoalan penelitian. Berdasarkan penelitian ini dapat dilihat bahwa sinetron Anak Langit ini berdampak negatif terhadap sebagian khalayaknya. Hal ini karena banyak pelanggaran yang terjadi, jika berpedoman pada regulasi penyiaran di Indonesia.
\end{abstract}

Kata Kunci : Televisi, Perilaku, Penyiaran, Sinetron

\begin{abstract}
This study aims to reveal how people's behavior after watching the soap opera Anak Langit and what are the factors that cause people's behavior to change after watching the soap opera Anak Langit. In addition, this study will also look at how violations that occur in Anak Langit soap operas are based on broadcasting regulations in Indonesia. This research will explore the existing problems using Cultivation Theory where this theory assumes that television exposure impacts on the community. This theory is based on Gerbner's thought which conveys that the continued exposure of the media will give an idea and influence on the perception of the viewer. That is, as long as viewers make contact with television they will learn about the world, change their perception of the world, learn to behave and people's values. This study uses qualitative methods, where researchers conduct literature studies, observations and interviews to approach and explore research problems. Based on this research it can be seen that the soap opera Anak Langit has a negative impact on some of its audience. This is because many violations occur, if guided by broadcasting regulations in Indonesia.
\end{abstract}

Keywords : Television, Behavior, Broadcasting, Soap Opera 


\section{PENDAHULUAN}

\section{Latar Belakang}

Di zaman modern ini perkembangan teknologi dapat sangat cepat tumbuh dan maju dengan pesat. Seiring berjalannya waktu, banyak teknologi terutama media yang terus tumbuh dan bertambah jenisnya. Sebut saja, beberapa media tersebut adalah media cetak, media elektronik, dan media online. Perkembangan media tersebut karena masyarakat haus akan informasi yang disajikan media. Informasi - informasi ini dianggap sebagai kebutuhan pokok yang harus ada dan tersedia di setiap saat. Selain kebutuhan informasi, alasan lain masyarakat membutuhkan media adalah terkait dengan kebutuhan hiburan masyarakat.

Mengapa siaran televisi begitu berbahaya bagi masyarakat jika tidak sesuai dengan norma-norman masyarakat Indonesia, hal ini seperti disampaikan Azwar (2017) dalam jurnalnya yang berjudul "Industri Televisi dan Wajah Buram Politik Indonesia" ia menyampaikan bahwa hal ini tentu saja berkaitan dengan keunggulan dari televisi itu sendiri. Di antara sekian banya media massa, televisi merupakan media yang memiliki keunggulan dan keistimewaan tersendiri untuk mempengaruhi penontonnya. Selain karena memiliki sifat audio dan visual, televisi juga memiliki keunggulan sebagai media yang selalu mendapatkan tempat di hati masyarakat.

Salah satu media yang mampu memenuhi kebutuhan masyarakat tersebut (kebutuhan akan informasi dan hiburan) adalah televisi. Televisi banyak digemari oleh masyarakat karena penggunaannya yang mudah, cepat, dan tidak membosankan karena televisi tidak hanya menyajikan gambar dan tulisan tetapi juga dengan suara. Banyak pihak berlomba-lomba untuk membangun dan meningkatkan kualitas stasiun yang dimilikinnya untuk memberikan informasi dan hiburan yang menarik bagi masyarakat. Walaupun pada saat ini perkembangan internet telah menyaingi televisi, namun keberadaan siaran-siaran televisi masih dibutuhkan masyarakat. Hal ini dapat dilihat dari masih banyaknya masyarakat yang memenuhi kebutuhan mereka terhadap informasi, hiburan, dan bahkan edukasi dari media televisi.

Televisi masih bertahan menjadi media yang dibutuhkan masyarakat karena televisi merupakan hasil produk teknologi tinggi (hi-tech) yang menyampaikan isi pesan dalam bentuk audio visual gerak. Isi pesan audio visual gerak memiliki kekuatan sangat tinggi untuk memengaruhi mental, pola pikir, dan tindak individu. Televisi dapat banyak memuat banyak program siaran yang ditayangkan, seperti misalnya berbagai macam berita, sinetron, iklan penjualan, dan lain sebagainya. Dengan tingkat kesibukan yang makin bertambah, televisi menjadi salah satu cara untuk masyarakat merelaksasikan pikirannya dan beristirahat sejenak dari padatnya pekerjaan yang sedang mereka lakukan.

Siaran televisi di Indonesia dimulai pada tahun 1962. Saat itu, masyarakat Indonesia disuguhi tontonan realita yang begitu memukau. Meskipun hanya siaran televisi hitam putih, tapi siaran pertama televisi di Indonesia itu menjadi momentum yang sangat bersejarah. Karena televisi menyajikan program yang ditayangkan dalam bentuk audio visual, maka televisi dapat mempengaruhi pola pikir dan tindak individu. Dengan seseorang melihat suatu kejadian atau suatu tindakan, maka hal tersebut akan terekam didalam hati dan otaknya. Dan dengan mendengar seseorang dapat terus mengingat apa saja informasi yang ia dengarkan sebelumnya.

Seharusnya televisi dapat menyuguhkan program yang dapat membuat pola pikir individu menjadi lebih baik dan memberikan kepuasan batin bagi orang yang menontonnya. Tetapi dalam kenyataannya saat ini banyak 
stasiun televisi swasta yang memiliki beberapa sinetron yang di dalamnya banyak mengandung adegan kekerasan yang ditonton oleh masyarakat yang sebagian besarnya adalah anak di bawah umur. Tak jarang juga banyak kata-kata tak pantas yang diucapkan dalam dialog acara tersebut.

Padahal berbagai macam adegan yang muncul dalam sinetron baik itu tindak kekerasan, pembicaraan kasar atau yang lainnya dapat dengan mudah diserap dan ditiru oleh para penonton yang dapat dikategorikan masih di bawah umur. Anak di bawah umur tergolong dapat cepat menangkap dan menirukan suatu hal yang mereka anggap menarik. Hal ini jelas menimbulkan pembentukan persepsi bagi orang yang menontonnya.

Memang benar bahwa fungsi televisi adalah untuk merelaksasikan (fungsi hiburan) diri dan juga memberikan pengetahuan (fungsi pendidikan) yang berkualitas dan dapat membentuk pola pikir yang baik. Tetapi, sangat disayangkan bahwa masih saja dapat ditemukan program siaran yang memiliki konten negatif di dalamnya. Banyak peraturan yang telah pemerintah buat sampai membentuk Komisi Penyiaran Indonesia (KPI) untuk membantu pemerintah memantau dan mengawasi jalannya acara acara yang disiarkan baik di televisi atau radio atau media lainnya.

Penelitian ini memilih program sinetron Anak Langit yang merupakan sekuel Anak Jalanan dari stasiun televisi SCTV ini sebagai kajian analisis, hal ini karena apa yang ditayangkan sebagian besar adalah berupa tindak kekerasan yang dilakukan oleh segerombolan anak muda yang masuk dalam geng motor dan tak jarang pula terdengar kalimat yang kesannya mengejek atau merendahkan saat kedua geng bertemu. Selain itu, sinetron yang dibintangi oleh pesinetron Stefan William, Ranty Maria, dan Ammar Zoni ini juga tayang pada waktu yang dapat dikatakan adalah waktu istirahat yang paling baik (prime time) karena saat sinetron ini tayang pada 19.30 WIB. Banyak masyarakat yang dapat melihat dan menikmatinya.

\section{Rumusan Masalah}

1. Bagaimana perilaku masyarakat setelah menonton sinetron Anak Langit dan apa faktor yang menyebabkan perilaku masyarakat menjadi berubah setelah menonton sinetron Anak Langit tersebut.

2. Bagaimana pelanggaran yang terjadi dalam sinetron Anak Langit berdasarkan peraturan/regulasi penyiaran di Indonesia.

\section{Tujuan Penelitian}

1. Untuk mengetahui perubahan perilaku masyarakat setelah menonton sinetron Anak Langit dan mengetahui faktor - faktor yang menyebabkan terjadinya perubahan perilaku dalam masyarakat.

2. Untuk mengetahui pelanggaran-pelanggaran apa saja yang terjadi dalam sinetron Anak Langit Lebih berdasarkan peraturan/regulasi penyiaran di Indonesia.

\section{Landasan Teori}

Kemajuan dan keberagaman program acara televisi memang menjadi hal penting di negara kita. Program acara yang sudah ada harus dikembangkan secara baik agar televisi tidak hanya menjadi sarana hiburan yang mendatangkan efek negatif bagi masyarakat. Bila kita berbicara tentang televisi khususnya penyiaran maka sangat erat hubungannya dengan teori kultivasi dan hukum pedoman penyiaran Indonesia. 


\section{Teori Kultivasi}

Teori kultivasi (cultivation) menurut Saverin dan Tankard (2008) dikembangkan untuk menjelaskan dampak menyaksikan televisi pada persepsi, sikap, dan nilai-nilai orang. Teori ini berasal dari program riset jangka panjang dan ekstensif yang dilakukan George Gebner beserta koleganya di Annenberg School of Communication di University of Pennsylvania. Lebih jauh Saverin dan Tankard menyampaikan bahwa Gebner dan koleganya mulai dengan argumentasi bahwa televisi telah menjadi tangan budaya terutama di Amerika Serikat, mereka mengutip pendapat Gebner bahwa televisi telah menjadi anggota keluarga yang penting, anggota yang bercerita paling banyak dan paling sering.

Teori kultivasi adalah teori yang memiliki hubungan yang erat terhadap televisi karena di dalam teori kultivasi membahas terpaan media dari televisi dan efek terhadap masyarakatnya. Seperti riset dari Gerbner yang membuktikan bahwa terpaan media yang terus menerus akan memberikan gambaran dan pengaruh pada persepsi pemirsanya. Artinya, selama pemirsa melakukan kontak dengan televisi mereka akan belajar tentang dunia, mengubah persepsi mereka akan dunia, belajar bersikap dan nilai-nilai orang.

Teori kultivasi pada dasarnya menyatakan bahwa para pecandu berat televisi membangun keyakinan yang berlebihan bahwa apa yang mereka lihat di televisi, yang cenderung menyajikan acara kekerasan, adalah apa yang mereka yakini terjadi juga dalam kehidupan sehari-hari (Romli, 2016 : 41 ). Gerbner menyatakan bahwa televisi merupakan suatu kekuatan yang secara dominan dapat mempengaruhi masyarakat modern. Kekuatan tersebut berasal dari kemampuan televisi melalui berbagai symbol untuk memberikan berbagai gambaran yang terlihat nyata dan penting seperti sebuah kehidupan sehari-hari. Televisi mampu mempengaruhi penontonnya.

Realitas yang tampil di media dipandang sebagai sebuah realitas objektif bagi para pengguna media. Sehingga terkadang media mampu mengatur dan mengubah pola pikir masyarakat. Masyarakat yang aktif atau melek media hanya sedikit bergantung dan memiliki keyakinan yang rendah pada media seperti televisi yang di dalamnya banyak terdapat settingan. Hal yang perlu diperhatikan disini adalah bagaimana penggunaan media berhubungan dengan tingkat kepercayaan terhadap media tersebut.

Seperti yang dikatakan oleh Gerbner yaitu fungsi utama televisi adalah untuk medium sosialisasi dan enkulturasi melalui isi tayangannya (drama) sehingga pemahaman akan televisi bisa menjadi sebuah pandangan ritual daripada hanya sebagai medium transmisi. (Romli, $2016: 40$ )

\section{Teori Normatif Media}

Selain Teori Kultivasi di dalam kasus penyiaran ini juga memiliki hubungan dengan Teori Normatif Media karena teori normatif media membahas tentang pembentukan norma yang dipengaruhi oleh media. Denis McQuail mengatakan dalam bukunya yaitu Teori Komunikasi Massa bahwa Teori Normatif Media adalah teori yang merujuk pada gagasan hak dan tanggung jawab yang mendasari pengharapan akan keuntungan media bagi individu dan masyarakat. (McQuail , 2011: 178)

Teori ini juga beranggapan bahwa norma-norma yang ada dimasyarakat dibentuk oleh pengaruh dari media. Maka dari itu apa yang ditampilkan oleh televisi akan sangat berpengaruh bagi masyarakat dalam pembentukan pola pikir dan tingkah laku, media sangat penting karena media membawa sejumlah tugas penting dan pokok dalam masyarakat kontemporer dan menjadi kepentingan umum agar tugas-tugas tersebut dijalankan dengan baik. 
Hal ini juga menyiratkan bahwa kita harus memiliki sistem media yang beroperasi menurut prinsip pemerintahan yang juga mengatur masyarakat, terutama yang berkaitan dengan keadilan, kebenaran, demokrasi, dan gagasan yang mengatur nilai sosial dan budaya yang diinginkan. Televisi sebagai media massa saat ini tidak mementingkan isi siaran yang ada di dalam programnya khususnya sinetron, media saat ini hanya mementingkan rating yang diperoleh dan profit yang di dapatkan, sehingga walaupun isi didalam konten tersebut mengandung kekerasan tetap saja ditayangkan.

Terlebih lagi, media biasanya dibangun tidak hanya untuk melayani kepentingan publik semacam itu, tetapi untuk mengikuti tujuan yang telah mereka buat yaitu mendapatkan rating yang bagus agar keuntungan dating kepada media tersebut. Media dalam masyarakat sebagian besar seharusnya memiliki kewajiban untuk membawa tujuan bernilai positif yang telah ditetapkan dan diterima begitu saja. Mereka tidak dijalankan oleh pemerintah maupun bekerja atas nama masyarakat. Tujuan positif dari aktivitas media tidak selalu atau tidak jelas terlihat, dan terkadang harus disimpulkan dari pernyataan mengenai apa yang tidak seharusnya mereka lakukan.

\section{Fungsi Media}

Kembali lagi kepada fungsi utama dari media massa itu sendiri bagi masyarakat seperti yang dikatakan oleh Denis McQuail (2011) fungsi utama dari media massa adalah informasi, korelasi, kesinambungan, hiburan, dan mobilisasi. Dalam fungsi hiburan ini dijabarkan lagi oleh McQuail bahwa hiburan berfungsi sebagai pengalihan perhatian, dan sarana relaksasi bagi masyarakat, dan hiburan juga berfungsi untuk meredakan ketegangan social. (McQuail, 2011: 72)

Sinetron masuk ke dalam hiburan, yang mana seharusnya sinetron berfungsi sebagai sarana relaksasi bagi masyarakat tetapi dalam realitanya sinetron tidak lagi menjadi sarana relaksasi bagi masyarakat, tetapi justru malah mendatangkan ketegangan sosial dan efek yang tidak bagus dimasyarakat. Seringkali hal tersebut terjadi kepada anak-anak yang dengan sangat mudah terkena terpaan dari sinetron tersebut. Hal ini ditakutkan kedepannya akan membuat psikologis anak itu sendiri menjadi tidak bagus.

\section{SP3S dan UU Penyiaran}

Sebenarnya peraturan penyiaran telah diatur dalam peraturan Komisi Penyiaran Indonesia Nomor 01/P/KPI/03/2012 tentang Pedoman Perilaku Penyiaran, tetapi tetap saja beberapa lembaga penyiaran dan Production House melakukan pelanggaran. Pelanggaran yang dibuat para perusahaan yang memproduksi sinetron kebanyakan adalah menampilkan unsur kekerasan saat menayangkan sinetron tersebut di televisi.

Dalam UU No. 23 tahun 2004 tentang Penghapusan Kekerasan Dalam Rumah Tangga sebenarnya sudah diatur bahwa dalam penyiaran tidak boleh menampilkan unsur kekerasan tetapi masih saja banyak lembaga penyiaran melanggarnya. Hal ini sangat menakutkan apabila terus ditampilkan unsur kekerasan karena bisa mempengaruhi pola pikir masyarakat.

Selain itu lembaga Komisi Penyiaran Indonesia juga sudah mengatur tentang aturan penyiaran dalam UU No. 32 Tahun 2002 tentang Penyiaran. Dan sudah jelas diatur dalam Pedoman Penyiaran BAB X tentang Perlindungan Kepada Anak pasal 14 di dalamnya dijelaskan bahwa "lembaga penyiaran wajib memberikan perlindungan dan pemberdayaan kepada anak dengan menyiarkan program siaran pada waktu yang tepat sesuai 
dengan penggolongan program siaran" dan juga pada ayat kedua dijelaskan "lembaga penyiaran wajib memperhatikan kepentingan anak dalam setiap aspek produksi siaran”.

Tetapi pada kenyataannya masih saja banyak pihak televisi yang tidak berpedoman pada Pedoman Penyiaran Indonesia. Selain Bab X dalam Bab XIII tentang Program Siaran Bermuatan Kekerasan pada pasal 17 juga tertera "lembaga penyiaran wajib tunduk pada ketentuan pelanggaran dan/atau pembatasan program siaran bermuatan kekerasan”. Dengan adanya Pedoman Penyiaran tersebut seharusnya bisa menjadi acuan atau landasan bagi para pembuat program televisi khususnya sinetron untuk membuat sinetron yang memiliki nilainilai yang sesuai dengan pedoman penyiaran, dan juga sesuai dengan nilai-nilai yang ada di masyarakat.

\section{METODE PENELITIAN}

Dalam penelitian ini kami menggunakan tinjauan meode penelitian kualitatif. Metode ini dipengaruhi atau berdasarkan perspektif teoritis yang digunakan untuk melakukan penelitian. Metode kualitatif bertujuan untuk menghasilkan hipotesis dari penelitian lapangan. Metode ini sebenarnya bersifat simplisitik, tetapi sering dikontraskan sebagaimana perspektif yang merupakan suatu rentang dari yang sangat objektif hingga sangat subjektif (Mulyana, 2013: 145-146) dengan menempatkan narasumber sebagai sumber untuk membahas permasalahan ini.

Dalam mendapatkan pembahasan penelitian, kami melakukan :

- Kajian kepustakaan dengan membaca berbagai referensi tertulis terkait dengan dampak televisi terhadap masyarakat.

- Observasi, peneliti melakukan observasi dengan mengamati bagaimana prilaku masyarakat yang menonton sionetron Anak Langit tersebut.

- Wawancara terbuka dengan narasumber. Wawancara adalah bentuk komunikasi antara dua orang, melihatkan seseorang yang ingin memperoleh informasi dari seseorang lainnya dengan mengajukan pertanyaan-pertanyaan, Berdasarkan tujuan tertentu. kami memilih wawancara terbuka agar mendapatkan jawaban yang luas dari responden terhadap kasus sinetron Anak Langit ini.

- Analisis Kultivasi dan Perundangan Penyiaran dengan menghubungkan respon dari khalayak terhadap efek dari sinetron, dan menghubungkan jawaban responden atas pertanyaan yang diajukan tentang permasalahan efek sinetron dihubungkan dengan literatur yang ada.

\section{HASIL DAN PEMBAHASAN}

Sinetron Anak Langit adalah salah satu sinetron yang didalamnya mengandung muatan konten negatif. Sinetron Anak Langit yang tayang di SCTV pada jam 19.30 WIB. Berkisah tentang tiga anak laki laki yang berasal dari panti asuhan bergabung dalam suatu geng motor berusaha membantu temannya untuk mendapatkan cinta seorang gadis dengan bersaing dengan ketua geng motor lain tetapi tak jarang bersaing dengan menggunakan berbagai macam kekerasan dan juga tindak kejahatan yang mudah ditiru para penontonnya.

Pada dasarnya, kisah ini merupakan sebuah hiburan bagi para masyarakat luas karena ceritanya akrab dengan kehidupan masyarakat sehari-hari. Tetapi, dalam penayangannya Anak Langit terlalu banyak mengeluarkan adegan perkelahian berujung kekerasan. Seperti berkelahi dengan saling memukul dan menendang, melakukan aksi kejahatan yang mudah ditiru dan tak jarang ada beberapa kalimat kasar yang keluar dalam dialog sang pemain.

94 | Azwar et al. : Dampak Sinetron Indonesia ... 
Berdasarkan observasi peneliti, peneliti menemukan anak-anak yang berdialog dengan teman-temannya dengan meniru dialog-dialog yang dipopulerkan dalam adegan sinetron tersebut. Hal ini karena anak-anak tersebut mengidolakan tokoh dalam sinetron itu sehingga mereka juga berbicara dan bersikap dengan meniru tokoh dalam sinetron. Hal ini berbahaya karena anak-anak sudah mencari idola yang salah, yang berbeda dari nilai-nilai yang ditanamkan oleh guru atau orang tua. Jika guru menanamkan nilai bahwa berkata kasar itu tidak baik, maka sinetron justru bertolak belakang dengan nilai yang disampaikan guru tersebut. Sayangnya, anakanak muda lebih mudah meniru sinetron daripada meniru guru mereka.

Sinetron Anak Langit, lebih banyak menyajikan tindak kekerasan dan kejahatan dibandingan memenuhi fungsinya untuk menanamkan dan menampilkan nilai-nilai seperti pendidikan, sosial, budaya, bahkan menumbuhkan contoh pada anak anak dan remaja akan lebih peduli dan mengenal lingkungannya. Dalam perjalanan penayangannya KPI sudah menegur acara ini karena banyaknya adegan kekerasan yang ditampilkan.

Apabila hal ini dilihat oleh anak anak yang berada di bawah umur dan lepas dari pengawasan orang tua, maka mereka akan dengan cepat menyerap apa yang baru saja mereka lihat. Bila dihubungkan dengan teori kultivasi, masyarakat yang sangat menyukai sinetron ini akan terbentuk suatu persepsi bahwa apa yang di ceritakan oleh Anak Langit ini benar adanya. Masyarakat dapat melakukan hal yang sama seperti dalam sinetron. Hal ini dapat terjadi karena mereka meyakini bahwa apa yang ditayangkan oleh televisi adalah benar adanya.

Media memiliki salah satu fungsi yaitu memberikan hiburan kepada para penggunanya. Televisi memberikan banyak hiburan dengan banyaknya film, sinetron, dan drama yang telah ditayangkan. Sinetron masuk ke dalam hiburan, yang mana seharusnya berfungsi sebagai sarana pemberi relaksasi bagi masyarakat tetapi dalam realitanya sinetron tidak lagi menjadi sarana relaksasi bagi masyarakat, tetapi justru malah mendatangkan ketegangan sosial dan efek yang tidak bagus dimasyarakat.

Dalam sinetron ini, banyak orang tua terutama para ibu rumah tangga yang khawatir apabila anak-anak mereka melakukan hal yang serupa, karena ada beberapa adegan kejahatan, kekerasan, dan berbahaya yang mudah ditiru oleh para anak mereka. Hal ini seperti yang disampaikan salah seorang orang tua yang mengatakan bahwa:

"Kami khawatir sebenarnya dengan adegan-adegan kekerasan dalam sinetron tersebut, tapi bagaimana lagi, kami tidak bisa mengontrol setiap saat apa yang ditonton anak-anak, karena kami juga punya kesibukan lain sebagai orang tua seperti menyiapkan makan malam atau menyiapkan pakaian mereka untuk sekolag besoknya,” (Wawancara RK, 20 Juli 2018)

Dari pernyataan salah satu informan tersebut di atas dapat dilihat bahwa kekhawatiran orang tua selalu ada karena anak-anak mereka menonton sinetron di televisi tersebut. Namun karena persoalan-persoalan lain, orang tua tidak selalu bisa mengontrol tindakan anak-anak mereka. Hal ini senada dengan informan selanjutnya yang menyampaikan bahwa:

"Kalaupun kita keras terhadap anak-anak, sekarang sudah tidak zamannya lagi. Kadang di rumah mungkin kita bisa mematikan televisi saat ada tayangan yang tidak baik, tapi kan tidak mungkin kita bisa mengontrol apa yang ditonton anak-anak setiap hari, apalagi kalau dikamarnya dia menonton kan tidak selalu bisa mengontrol, apalagi kita orang tua menganggap mereka sudah dewasa," (Wawancara NN, 20 Juli 2018) 
Dalam Anak Langit, berbagai tindak kekerasan fisik ini menimbulkan kecemasan dan ketakutan tersendiri. Karena dengan terlihatnya citra geng motor yang dianggap bising dan menyeramkan, juga selalu bermain kasar saat ingin mendapatkan sesuatu. Terbukti bila sinetron di Indonesia walaupun sepintas memberikan hiburan kepada para penontonnya, tetapi ada dampak lain yang ditimbulkan, yaitu berupa ketegangan sosial yang diantaranya ada kecemasan dan ketakutan akan geng motor. Efek yang ditimbulkan pun juga tidak terlalu bagus karena perilaku seorang anak dapat berubah setelah melihat tayangan ini. Walaupun menayangkan suatu acara hiburan tetapi seharusnya televisi Indonesia tetap tidak melupakan fungsinya untuk memberikan pengetahuan dan relaksasi bagi para penontonnya. Hal ini seperti yang disampaikan narasumber berikut:

"Kita kan nonton televisi untuk hiburan saja, tapi ya.., kadang siarannya tidak sesuai juga dengan kebutuhan masyarakat Indonesia, kadang tidak sesuai dengan norma-norma yang sudah ada di negara atau masyarakat kita," (Wawancara AR, 20 Juli 2018)

Dalam peraturan penyiaran pun, seperti dalam UU No. 23 tahun 2004 tentang Penghapusan Kekerasan Dalam Rumah Tangga sejelas jelasnya telah dikatakan bahwa dalam penyiaran tidak boleh menampilkan unsur kekerasan. Tetapi tetap masih saja banyak lembaga penyiaran yang melanggarnya. Tetap menggunakan kekerasan sebagai konten acar amereka. Hal ini sangat menakutkan apabila terus ditampilkan unsur kekerasan karena bisa mempengaruhi pola pikir masyarakat terhadap geng motor, juga pada lingkungan sekitarnya.

Pedoman Penyiaran BAB X tentang Perlindungan Kepada Anak pasal 14 di dalamnya dijelaskan pada ayat kedua bahwa lembaga penyiaran wajib memperhatikan kepentingan anak dalam setiap aspek produksi siaran, dalam hal ini sinetron Anak Langit berada pada jam anak - anak berada di rumah dan beristirahat sambil menonton tv.

Disini aspek yang dilanggar adalah tidak sesuainya konten yang dapat membuat anak dibawah umur meniru atau bahkan melakukan tindakan yang sesuai dengan apa yang telah dilihat dalam suatu adegan sinetron. Misal, seorang anak menirukan bagaimana cara para pemain sinetron Anak Langit dalam mengendarai motor secara ugal-ugalan dan kebut - kebutan, hal ini akan berujung pada perubahan perilaku yang dimana semula anak berhati-hati mengendarai motor tetapi sekarang justru mencoba adegan berbahaya ini. Ditambah dengan di zaman sekarang, anak di bawah umur tidak terlalu diperhatikan dalam membawa kendaraan.

Teori normatif media beranggapan bahwa norma-norma yang ada di masyarakat dibentuk oleh pengaruh dari media. Maka dari itu apa yang ditampilkan oleh televisi akan sangat berpengaruh bagi masyarakat dalam pembentukan pola pikir dan tingkah laku, media sangat penting karena media membawa sejumlah tugas penting dan pokok dalam masyarakat kontemporer dan menjadi kepentingan umum agar tugas-tugas tersebut dijalankan dengan baik. Hal ini sebagaimana yang disampaikan oleh Dosen Ilmu Komunikasi FISIP UPN Veteran Jakarta yang juga pengamat media menyampaikan bahwa:

"Sejatinya media bisa dimanfaatkan untuk tujuan-tujuan positif dalam masyarakat, seperti fungsi menyampaikan informasi dan memberikan edukasi, namun sayangnya tidak semua produsen siaran televisi itu yang sepakat dengan norma-norma yang ada. Kita tidak satu suara terhadap norma apa yang boleh dan tidak boleh di media, walaupun sejatinya sudah diatur dalam regulasi penyiaran kita," (Wawancara AP, 23 Juli 2018).

Terkait dnegan standar norma ini tentu saja hal ini berbeda-beda, namun sebagaimana yang disampaikan AP bahwa sejatinya rujukan utamanya bisa pada regulasi yang sudah ada seperti peraturan KPI. Lebih jauh disampaikan: 
"Persoalan lain adalah rendahnya upaya penegakan atas regulasi yang ada. KPI sebagai lembaga yang konsen terhadap hal ini kadang tidak bisa menangani semua pelanggaran yang ada di media, oleh sebab itu, tidak bisa semua persoalan ini ditumpukan kepada KPI, tapi partisipasi masyarakat juga penting," (Wawancara AP, 23 Juli 2018).

Sejatinya media mampu membawa berbagai informasi dan hiburan yang positif dan menambah pengetahuan secara lebih luas lagi, namun dalam sinetron Anak Langit banyaknya tindak kekerasan seperti memukul dan mencelakakan dapat sangat membahayakan lingkungan dalam masyarakat karena apabila banyak masyarakat yang melakukan ini maka jumlah kriminalitas akan bertambah. Selain itu, perilaku yang dimiliki suatu masyarakat yang tidak bisa menyaring adegan dalam sinetron dapat berubah menjadi buruk.

Karena, dengan melihat suatu tayangan dan kita menyukainya kita akan ikut melakukan itu. Dengan melakukannya kita telah mengalami perubahan tingkah laku seperti saat kita ingin meminta sesuatu dan itu tidak terpenuhi kita menggunakan banyak kalimat kasar atau membentak bahkan berani melukai orang agar tujuan kita tercapai.

Televisi sebagai media massa seharusnya menjadi wadah untuk mengekspresikan suatu permasalahan atau menayangkan banyak hal mengenai budaya Indonesia, tetapi justru pada saat ini kebanyakan televisi tidak mementingkan isi siaran yang ada di dalam programnya khususnya sinetro. Media saat ini hanya mementingkan rating yang diperoleh dan profit yang di dapatkan, sehingga walaupun isi didalam konten tersebut mengandung kekerasan tetap saja ditayangkan. Karena dengan tingginya rating suatu acara, maka membuktikan bahwa acara tersebut banyak disukai dan diakui.

\section{PENUTUP}

Dari apa yang telah dibahas, dapat disimpulkan bahwa televisi merupakan salah satu contoh media yang digunakan untuk menyebarkan berbagi macam informasi yang ada. Selain itu televisi memiliki fungsi antara lain adalah sebagai pemberi hiburan kepada para penontonnya. Televisi Indonesia memiliki ciri khas penayangan acara televisi dengan konten berupa masalah-masalah yang tak asing didengar oleh masyarakat tetapi cederung yang dibahas lebih kearah masalah negatif.

Terutama televisi di Indonesia belum seutuhnya pintar menyaring konten siaran dan menaati peraturan yang telah dibuat. Selain itu, sinetron yang ada di Indonesia masih banyak yang menggunakan konten negative dan melupakan fungsinya sebagai pemberi hiburan dan justru menimbulkan keresahan dan ketegangan sosial. Dalam sinetron Anak Lagit masih ditemukan hal-hal yang bertentangan dengan regulasi penyiaran. Masih ada suatu acara televisi dengan tidak mematuhi aturan yang telah dibuat dan cederung melanggarnya. Banyak dari mereka yang lebih mementingkan rating program dibandingkan apa yang ingin mereka berikan dan sampaikan kepada masyarakat yang menjadi target sasaran mereka.

Perubahan perilaku dan pola pikir masyarakat terhadap suatu permasalahan di lingkunganya dapat terlihat dari tayangan seperti apa yang mereka tonton. Semakin bagus dan berisi banyak pengetahuan, maka masyarakat akan pintar dan pandai menangani setiap permasalahan juga menghadapi kehidupannya sehari hari. Sebaliknya, bila masyarakat menonton tayangan yang berisikan hal - hal negative maka pola perilaku dan cara berpikir mereka akan mengikuti apa yang telah mereka tonton.

Sinetron Anak Langit adalah salah satu contoh jenis acara televisi yang menyajikan cerita yang tak asing di masyarakat tetapi banyak mengandung konten negatif yang mudah ditiru oleh anak-anak dan remaja yang 
menontonnya. Dapat terlihat dari banyaknya adegan kekerasan, kejahatan, dan beberapa dialog tak pantas yang digunakan. Hal ini menimbulkan dampak berupa rasa cemas terutama bagi ibu rumah tangga dan perubahan perilaku masyarakat dalam menghadapi masalah yang ada di lingkungannya.

Ada beberapa saran yang dapat disampaikan yaitu (1) KPI harus lebih memperketat pengawasan terkait dengan banyaknya konten yang tidak memenuhi syarat penyiaran dan bagaimana regulasinya pada saat acara itu ditayangkan. (2) Lembaga penyiaran harus lebih pintar dalam memilih dan memilah mana konten yang ingin diproduksi dan ditayangkan. (3) Masyarakat dihimbau untuk lebih teliti, dan pintar menyaring berbagai macam informasi yang ada baik dari tayangan hiburan di televisi.

\section{DAFTAR PUSTAKA}

Azwar. 2017. Industri Televisi dan Wajah Buram Politik Indonesia. Jakarta: Jurnal Komunika: Jurnal Komunikasi, Media dan Informatika.

Baksin, Askurifai. 2016. Jurnalistik Televisi Teori dan Praktik. Bandung: Simbiosa Rekatama Media.

Mulyana, Deddy. 2013. Metodologi Penelitian Kualitatif. Bandung: PT. Remaja Rosdakarya.

McQuail, Denis. 2011. Teori Komunikasi Massa. Jakarta: PT. Salemba Humanika.

Romli, Khomsahrial. 2016. Komunikasi Massa. Jakarta: PT. Grasindo.

Rasyid, M. Riyanto. 2013. Kedaulatan Frekuensi. Jakarta: Kompas Media Nusantara

Saverin, Werner J dan James W Tankard (2008) Teori Komunikasi Sejarah, Metode, dan Terapan, di Dalam Media Massa, Jakarta: Kencana Prenada Media.

Surokim. 2000. Pengaturan Tentang Kekerasan Dalam Program Siaran TV. Madura: Universitas Trunojoyo. 